\title{
REVIEW
}

\section{The standard of care of patients with ARDS: ventilatory settings and rescue therapies for refractory hypoxemia}

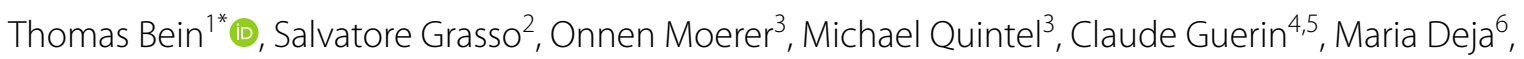
Anita Brondani ${ }^{7}$ and Sangeeta Mehta ${ }^{7}$

(c) 2016 The Author(s). This article is published with open access at Springerlink.com

\begin{abstract}
Purpose: Severe ARDS is often associated with refractory hypoxemia, and early identification and treatment of hypoxemia is mandatory. For the management of severe ARDS ventilator settings, positioning therapy, infection control, and supportive measures are essential to improve survival.

Methods and results: A precise definition of life-threating hypoxemia is not identified. Typical clinical determinations are: arterial partial pressure of oxygen $<60 \mathrm{mmHg}$ and/or arterial oxygenation $<88 \%$ and/or the ratio of $\mathrm{PaO}_{2} / \mathrm{FIO}_{2}<100$. For mechanical ventilation specific settings are recommended: limitation of tidal volume (6 ml/ $\mathrm{kg}$ predicted body weight), adequate high PEEP $\left(>12 \mathrm{cmH}_{2} \mathrm{O}\right)$, a recruitment manoeuvre in special situations, and a 'balanced'respiratory rate (20-30/min). Individual bedside methods to guide PEEP/recruitment (e.g., transpulmonary pressure) are not (yet) available. Prone positioning [early ( $\leq 48 \mathrm{hrs}$ after onset of severe ARDS) and prolonged (repetition of 16-hr-sessions)] improves survival. An advanced infection management/control includes early diagnosis of bacterial, atypical, viral and fungal specimen (blood culture, bronchoalveolar lavage), and of infection sources by CT scan, followed by administration of broad-spectrum anti-infectives. Neuromuscular blockage (Cisatracurium $\leq 48$ hrs after onset of ARDS), as well as an adequate sedation strategy (score guided) is an important supportive therapy. A negative fluid balance is associated with improved lung function and the use of hemofiltration might be indicated for specific indications.
\end{abstract}

Conclusions: A specific standard of care is required for the management of severe ARDS with refractory hypoxemia. Keywords: Acute respiratory distress syndrome, Refractory hypoxemia, Ventilatory settings, Prone positioning, Infection management, Neuromuscular blockade

\footnotetext{
*Correspondence: thomas.bein@klinik.uni-regensburg.de; thomas.bein@ ukr.de

${ }^{1}$ Department of Anesthesia, Operative Intensive Care, University Hospital Regensburg, 93042 Regensburg, Germany

Full author information is available at the end of the article
}

Take-home message: For the management of severe ARDS, ventilator settings, positioning therapy, infection control, and supportive measures are introduced.

\section{空 Springer}




\section{Introduction: hypoxemia in ARDS: definition, monitoring, and pitfalls}

The acute respiratory distress syndrome (ARDS) is characterized by life-threatening impairment of pulmonary gas exchange, resulting in hypoxemia, hypercapnia, and respiratory acidosis and requiring acute rescue measures. Oxygen delivery to the tissues is necessary for all aerobic life, and tissue hypoxia will result in various deleterious effects including altered vascular reactivity, inflammation, cell apoptosis, and organ dysfunction or failure [1]. Tissue hypoxia is the result of hypoxemia, and hypoxemia is a consequence of insufficient support of the respiratory system and/or of the oxygen delivery system (cardiac output, hemoglobin level [2]). Unfortunately, a precise and "simple" limit area to hypoxemia has not been identified and a "critical" level at which harm appears might vary between organs and patients. Furthermore, it is not known whether critically ill patients have the same spectrum of compensatory mechanisms to hypoxemia as the "normal" human body, and the rapidity of onset ("acclimatization effect"), severity, and duration of hypoxemia may determine the induction of tissue hypoxia.

A clinical determination of hypoxemia varies, but typical values are

- Arterial partial pressure of oxygen $\left(\mathrm{PaO}_{2}\right)<60 \mathrm{mmHg}$.

- A ratio of $\mathrm{PaO}_{2}$ to $\mathrm{FIO}_{2}<100$.

- Arterial oxygenation (pulse oximetry $\left[\mathrm{SaO}_{2}\right]$ ) $<88 \%$.

In recent years a strategy of permissive hypoxemia $\left(\mathrm{SaO}_{2} 82-88 \%\right)$ in patients with severe ARDS was proposed aimed at minimizing the harmful effects of high inspiratory oxygen concentrations by accepting a low $\mathrm{SaO}_{2}$ and optimizing cardiac output to maintain adequate oxygen delivery [3]. Of note the "classical" concept of oxygen delivery/consumption dependency is controversial [4]. A recent Cochrane review failed to identify any relevant studies evaluating hypoxemia versus normoxemia in ventilated patients with ARDS [5]. Furthermore, in a retrospective analysis of ARDS patients, lower $\mathrm{PaO}_{2}$ during mechanical ventilation (median $<72 \mathrm{mmHg}$ ) was associated with a higher incidence of long-term cognitive impairment and psychiatric disorders compared with higher $\mathrm{PaO}_{2}$ (median $86 \mathrm{mmHg}, p<0.02$ ) [6].

Hypoxemia and tissue hypoxia could be detected by $\mathrm{PaO}_{2}, \mathrm{SaO}_{2}$, serum lactate, and central venous oxygen saturation $\left(\mathrm{SvO}_{2}\right)$, which are global measurements, and the extent to which these flow/volume-average-weighted measurements reflect organ hypoxia remains unknown. In clinical practice the definition of "hypoxemia" is often based on one or more of these global values, and currently no parameter for the precise assessment of tissue hypoxia in the individual patient is available. Since inadequate tissue oxygenation as well as excessive oxygen administration (with expression of oxygen reactive species) can both be harmful [7], a careful balance based on precise control of arterial oxygenation including the acceptance of a "safe" threshold may avoid deleterious hypoxia as well as hyperoxia-associated injury. It remains to be evaluated in further studies whether selected biomarkers may help identify tissue hypoxia in the individual patient.

In summary, "simple" and global parameters $\left(\mathrm{PaO}_{2}\right.$, $\mathrm{SaO}_{2}, \mathrm{SvO}_{2}$, lactate) are imprecise surrogates for hypoxia in ARDS patients. However an individualized, organ-specific approach for monitoring of hypoxemia is currently not available. Therefore a target for conservative arterial oxygenation is recommended $\left(\mathrm{PaO}_{2}=65-75 \mathrm{mmHg}\right.$, $\mathrm{SaO}_{2}=90-95 \%$ ), which should be bundled in a general "organ failure prevention" strategy.

\section{Ventilatory setting I: tidal volume/respiratory rate Low tidal volume in hypoxemic ARDS}

Low $V_{\mathrm{T}}$ ventilation $(6 \mathrm{ml} / \mathrm{kg}$ predicted body weight, PBW) reduces 28-day and total hospital mortality [8], but PBW-based $V_{\mathrm{T}}$ ignores the lung volume actually available for ventilation. The applied volume is only distributed to aerated regions, and the larger the non-aerated regions, the greater the associated hyperinflation (strain). The driving pressure for a given $V_{\mathrm{T}}$ is responsible for opening lung areas which are collapsed at end-expiration. A lower pressure will not reopen these areas and hypoxemia will worsen. The solution is to increase PEEP in order to reap the potential benefits of such a protective approach, especially in severe ARDS. This will also reduce the driving pressure required $[9,10]$. It would allow more individualized settings based on physiologic measurements and considerations [11-13].

\section{Volume- or pressure-controlled mode}

Whether pressure-controlled ventilation (PCV) can reduce ventilator-associated lung injury (VALI) compared to volume-controlled ( $\mathrm{VCV}$ ) ventilation is a matter of debate. A meta-analysis [14] of three randomized controlled trials (RCTs) concluded that PCV was not superior to VCV, with a relative risk of hospital and ICU mortality for PCV versus VCV of 0.83 (95 \% CI $0.67-$ $1.02 ; p=0.08$ ) and 0.84 (95\% CI $0.71-0.99 ; p=0.04$ ), respectively. Another systematic review which included 34 studies concluded that outcome is "unlikely influenced by simply using one breath type vs the other for all patients" [15]. Since flow, driving pressure, and frequency determine the power, and the factor by which ventilation injures the lungs, it seems unlikely that the manner in which this power is delivered (i.e., flow pattern) plays a major role. Airway pressure release ventilation provides 
a potential recruitment by increased airway pressure and allows spontaneous breathing, with some potential benefits (decreased sedation, shorter mechanical ventilation, and improvement in cardiac performance). Highfrequency oscillatory ventilation delivers very small tidal volumes, to prevent volutrauma, at a constant (relatively high) mean airway pressure. Despite their theoretical benefits, the clinical evidence of both techniques remains unproven and controversial for ARDS patients [16].

\section{Respiratory rate}

The effect of respiratory rate (RR) on the occurrence of VALI or outcome in ARDS has not been independently studied. Lung injury may be related to the frequency of repetitive collapse and expansion [17], i.e., how often the lungs are exposed to a given stress and strain. The degree of tissue damage probably depends on the pressure amplitude and to a lesser extent on the frequency with which it is applied $[18,19]$. However, a higher respiratory rate might prevent expiratory derecruitment by reducing expiratory time and causing intrinsic PEEP [20]. In a large animal model of VALI, higher RR was associated with less pulmonary inflammation, but increased lung edema [21]. Accordingly, a high RR might influence the amount of extrinsic PEEP, and the current status of the lungs in terms of (de)recruitment, regional compliance, and resistance.

\section{Inspiratory/expiratory (I:E) ratio}

Increasing inspiratory time has been suggested to improve oxygenation. The effect of a high I:E ratio in hypoxemic ARDS patients is related to the resultant increase in intrinsic PEEP (PEEPi), improved ventilation of units with long time constants, and alveolar recruitment secondary to increased mean airway pressure $\left(M_{\mathrm{PAW}}\right)$ [22]. The results regarding the effect of different I:E ratios are conflicting [22, 23]. Reported positive effects have been ascribed to the shortening of expiratory time, increased $M_{\mathrm{PAW}}$ and PEEPi [24]. Using extrinsic PEEP is perhaps the more physiological approach as it maintains a controlled and constant level. Moreover, the impact of an inconstant PEEPi on the "stress/strain $\times$ time product" for the pathogenesis of VALI calls for caution [25].

\section{Specific ventilator mechanics: heat and moisture exchangers/humidifier}

Heating and humidifying the inspiratory gas with heated humidifiers or heat and moisture exchangers compensates for the bypassed humidification/heating mechanisms and prevents associated complications [26]. Heat and moisture exchangers are widely used because of low cost, simple handling, and condensate elimination from the breathing circuit. However, they increase dead space and airway resistance, as well as work of breathing during assisted ventilation with the risk of hypercapnia [27]. In ARDS patients, heated humidifiers but not heat and moisture exchangers can safely reduce $\mathrm{PaCO}_{2}$ without changing ventilator settings [28]. In 17 acute lung injury (ALI)/ARDS patients $V_{\mathrm{T}}$ was significantly reduced using heated humidifiers [29]. These findings question the use of heat and moisture exchangers in ARDS patients, where the primary target is to provide the optimum lung-protective ventilation.

\section{Ventilatory settings II: PEEP/recruitment}

Alveolar recruitment, obtained through positive endexpiratory pressure (PEEP) and/or lung recruiting maneuvers (LRMs), has been used to improve hypoxemia in patients with ARDS since the early 1970s, just after the first description of the syndrome [30]. At present, the aim of alveolar recruitment is not only to improve oxygenation but also to prevent VALI by minimizing tidal alveolar opening and collapse (atelectrauma) [31]. However, despite a myriad of clinical and translational studies and three large clinical trials, the effectiveness of recruitment remains controversial [32-35]. One "simple" reason is that clinicians lack bedside methods to quantify alveolar recruitment and its impact on VILI. Hence, decisions are based on surrogates, such as arterial oxygenation, endinspiratory plateau pressure, or driving pressure. Electrical impedance tomography (EIT), lung ultrasound, and the stress index have been proposed to monitor alveolar recruitment, but are seldom used in clinical practice [11, 36].

At present, the only evidence-based protocol for setting PEEP is the one proposed by the ARDS Network (ARDSNet) in a pivotal study [8]. However in that study the PEEP and $\mathrm{FiO}_{2}$ combination was the same for the control and study arm and LRMs were not permitted. Overall, the ARDSNet protocol just "tolerates" atelectasis by applying the minimal PEEP and $\mathrm{FiO}_{2}$ to match an acceptable (but rather low) arterial oxygenation target (between 55 and $80 \mathrm{mmHg}$ ). Nevertheless, two major issues remain controversial: prevention of the main VILI mechanisms (tidal recruitment and hyperinflation) [9], and the best "rescue" protocol to be adopted if the ARDSNet protocol fails (i.e., if oxygenation targets are not reached within the $\mathrm{PEEP} / \mathrm{FiO}_{2}$ and/or inspiratory plateau pressure limits imposed by the protocol). The overall side effects and complications associated with mechanical ventilation are summarized in Table 1.

A meta-analysis of the three major clinical trials [37] evaluated the first issue and suggested that the application of LRMs and PEEP levels higher than those suggested by the ARDSNet protocol could improve both lung aeration and clinical outcome. 
Table 1 Incidence of side effects and complications of mechanical ventilation in ARDS

\begin{tabular}{|c|c|c|}
\hline Side effect/complication & Incidence & Comment \\
\hline Ventilator-associated lung injury (VALI) & Not known & $\begin{array}{l}\text { Incidence and intensity depend on invasiveness/duration } \\
\text { of mechanical ventilation }\end{array}$ \\
\hline Ventilation-associated pneumonia (VAP) & $14-28 \%$ & $\begin{array}{l}\text { Problem: incidence depends on VAP definition; incidence } \\
\text { increases with duration and invasiveness of mechanical } \\
\text { ventilation }\end{array}$ \\
\hline Right ventricular dysfunction, acute cor pulmonale & Up to $50 \%$ & Often associated with severe hypercapnia/acidosis \\
\hline Pleural effusions & Up to $80 \%$ & $\begin{array}{l}\text { Frequently related to fluid overload, hypo-oncotic states, } \\
\text { cardiac dysfunction, and altered pleural pressure }\end{array}$ \\
\hline Barotrauma/pneumothorax & $6-12 \%$ & $\begin{array}{l}\text { Depends on the invasiveness }\left(P_{\text {Plat }}\right) \text { of mechanical } \\
\text { ventilation }\end{array}$ \\
\hline Damage of other organ systems via cross talk & Not known exactly & $\begin{array}{l}\text { Lung, brain, and-renal cross talk via inflammation } \\
\text { pathways }\end{array}$ \\
\hline Prolonged sedation and immobilization & Not known & $\begin{array}{l}\text { Incidence and intensity depend on sedation strategy, } \\
\text { (early) wake up, and spontaneous breathing trials }\end{array}$ \\
\hline Fibroproliferative response of the lung parenchyma & Up to $50 \%$ in the "lung-protective era" & $\begin{array}{l}\text { Decrements in lung function (vital capacity, forced expira- } \\
\text { tory volume) up to } 5 \text { years after discharge }\end{array}$ \\
\hline
\end{tabular}

The second issue is a major clinical challenge in a small, but not negligible, cohort of patients. The first approach to persistent severe hypoxemia should be prone position [38] and neuromuscular blockade [39]. If these do not adequately improve oxygenation, patients are candidates for a "rescue" maximal alveolar recruitment. The simplest, though smart, "open lung approach" is the one proposed by the Express study [33], which was not exclusively dedicated for "rescue" patients. Briefly, it consists of a stepwise PEEP increase up to an end-inspiratory plateau pressure of $30-32 \mathrm{cmH}_{2} \mathrm{O}\left(35 \mathrm{cmH}_{2} \mathrm{O}\right.$ if impaired chest wall elastance is likely), while ventilating with low tidal volumes $\left(V_{\mathrm{T}}\right.$, i.e., 4-6 $\mathrm{ml} / \mathrm{kg}$ PBW). LRMs were not mandatory in the Express protocol; however, in "difficult to ventilate" patients they were strongly advised before PEEP titration. Another important approach, though seldom applied in clinical practice, is to optimize the transpulmonary pressure $\left(P_{\mathrm{L}}\right)$. Indeed during PEEP and LRMs the driving pressure delivered by the ventilator consists of two components: one to inflate the lung $\left(P_{\mathrm{L}}\right)$ and one to expand the chest wall. Simultaneously measuring the airway opening and the esophageal pressure swings generated by positive pressure tidal inflation allows partitioning of the mechanical properties of the lung and chest wall. Accordingly PEEP and LRMs can be titrated safely to an "optimal" $P_{\mathrm{L}}$ target. Recent evidence suggests that this could improve "refractory" hypoxemia [40]. The most aggressive open lung approach has been proposed by Barbas et al. [41] and is based on the physiological evidence that alveolar recruitment is a multi-inspiratory phenomenon and the critical "opening pressure" of atelectatic lung units is higher than the pressure needed to keep them open. Barbas et al. [41] proposed to titrate PEEP on the expiratory limb of the respiratory volume-pressure curve (to match the best compliance or the best oxygenation) immediately after a "maximal" LRM. The latter consists of a stepwise PEEP increase up to $45 \mathrm{cmH}_{2} \mathrm{O}$, while ventilating the patient with a pressure drive of $10-15 \mathrm{cmH}_{2} \mathrm{O}$.

The open lung approach may dramatically improve oxygenation, while minimizing VALI. The potential for alveolar recruitment in the individual patient is unfortunately extremely variable and difficult to estimate a priori [42]. As a general rule, patients with early, diffuse ARDS are good recruiters, whereas patients with late ARDS (>1 week) or focal ARDS are not [35, 43]. In poor recruiters, the open lung approach may induce alveolar hyperinflation and hence VALI [31]. The stress index (identification of injurious mechanical ventilation from the shape of the pressure-volume curve) could be a valuable tool to monitor open lung approach-induced hyperinflation [11]. Another potential adverse effect of the open lung approach is the hemodynamic impairment due to reduced preload or increased right ventricular afterload [44].

\section{Positioning}

\section{Indications for prone position}

Prone position ventilation consists of delivering mechanical ventilation to the patient turned face-down. This method frequently and sometimes markedly improves oxygenation in patients with ARDS [45]. As a treatment, prone position ventilation results in significantly better oxygenation than mechanical ventilation applied in the supine position in ARDS patients [46]. As such prone positioning is used as an important strategy in life-threatening hypoxemia to avoid serious adverse events or death due to severe hypoxemia. In an individual patient-data 
meta-analysis of four large RCTs, prone position was associated with a significantly better survival rate in ARDS patients with $\mathrm{PaO}_{2} / \mathrm{FiO}_{2}<100 \mathrm{mmHg}$ [47]. However, in a recent trial that showed significantly better survival in the prone position group compared to the supine position [48] in patients with moderate to severe ARDS, the benefit of proning was observed at any level of hypoxemia at the time of randomization and no correlation was found between the magnitude of oxygenation response of the first session and patient survival [49]. Therefore, the beneficial effect of proning is likely explained by factors other than improvement in oxygenation. Among them the prevention of VALI $[50,51]$ is likely a major contributing factor to the benefit of proning. As such, it should be applied as first-line therapy to any patient with moderate or severe ARDS.

\section{Timing and duration}

It should be stressed that the effect of proning on VILI prevention is distinct from its effect on oxygenation. Henceforth, proning should be applied as early as possible after identification of hypoxemic ARDS to make the lung more homogeneous and to reduce the stress and strain [52] imposed on the entire lung by mechanical ventilation. In the Proseva trial, however, patients were, enrolled after a 12- to 24-h stabilization period which was used to confirm ARDS. It is likely that this strategy led to selecting patients with a more recruitable and more heterogeneous lung [53], which would benefit from proning. Nevertheless, the control group was not disfavored as its mortality was exactly the same as in another trial on similar patients [54].

Early trials used proning for 7- to 8-h sessions [55, 56]. It turned out that using longer session lasting more than $12 \mathrm{~h}$ was feasible $[57,58]$. In the Proseva trial the mean session duration was $17 \mathrm{~h}$ and the proning treatment was used during 4 days on average. In the PSII trial [57], these values were $18 \mathrm{~h}$ and 8 days, respectively. The criterion to stop proning was defined in the Proseva trial as an improvement in oxygenation for at last $4 \mathrm{~h}$ in the supine position $\left(\mathrm{PaO}_{2} / \mathrm{FIO}_{2}>150 \mathrm{mmHg}\right.$ with PEEP $<10 \mathrm{cmH}_{2} \mathrm{O}$ and $\left.\mathrm{FiO}_{2}<0.6\right)$. In the PSII trial the prone position was stopped once acute respiratory failure resolved $\left(\mathrm{PaO}_{2} / \mathrm{FIO}_{2}\right.$ in supine similar to prone position). These two strategies resulted in different doses of proning, amounting to 73 and $50 \%$, respectively, of the time allocated to prone actually spent in this position.

\section{Risk management/safety}

It is interesting to note that in many centers that have used prone position for many years the procedure is simple and done routinely by $3-4$ caregivers. In other centers which do not prone patients frequently the procedure is described as complex, cumbersome, and risky. It should be stressed that the procedure really needs a specific implementation program in the ICU and it is likely that, as for other techniques, the volume effect does matter. In the last meta-analyses of trials on prone versus supine position $[58,59]$, pressure sores and endotracheal tube obstruction were still significantly more frequent with proning. It should also be stressed that no trial showed harmful effects of prone position as a group.

\section{Contraindications}

Specific contraindications to proning have been defined in the trials. The likely single absolute contraindication is an unstable spine fracture. All other contraindications (Table 2) are relative and the benefit-to-risk balance should favor proning. It is worth noting from Table 2 that an acute abdomen was not a contraindication to prone position.

\section{Advanced infection management in early ARDS}

In the early phase of ARDS, at the time of admission to an ARDS center a lung and whole body computed tomography (CT) may be performed especially in the combination of sepsis and ARDS-if the indication is supported by careful anamnesis, clinical history, and examination-to diagnose (a) focus of infection as the major cause of ARDS; (b) typical complications of ARDS; (c) concomitant disorders requiring therapeutic interventions; and (d) risk factors for extracorporeal lung support. CT is performed for detection of several causal agents of infection (pulmonary infiltrates, ground glass opacities, pleural effusions, pleural empyema, lung abscess, lymphadenopathy, cerebral abscess, cerebral septic embolus, intra-abdominal abscess or infection). Transesophageal echocardiography is useful to exclude endocarditis and pericardial effusion and to assess right and left ventricular function. Flexible bronchoscopy is used as a diagnostic/therapeutic procedure but hypoxemia and hypercapnia may occur during bronchoscopy, and severe hypoxemia $\left(\mathrm{PaO}_{2} / \mathrm{FiO}_{2}<100\right)$ might be seen as a contraindication for bronchoalveolar lavage (BAL). Protected specimen brush is used rarely, as it is costly and disposable.

\section{Laboratory examination for diagnosis of infection}

Major causes of ARDS are infections. Blood cultures (BC: $2 \times 2$ pair $\geq 30 \mathrm{ml}$ blood volume, sterile conditions, before anti-infective treatment) are essential clinical diagnostics. A specific anti-infective strategy based on culture results is more effective compared to empiric broadspectrum treatment [60]. New techniques (e.g., polymerase chain reaction $[\mathrm{PCR}]$ and deoxyribonucleic acid [DNA] amplification, microarray and/or matrix-assisted 
Table 2 Contraindications to prone positioning defined in the trials

\begin{tabular}{|c|c|c|c|}
\hline Gattinoni [55] & Guérin $[48,54]$ & Mancebo [56] & Taccone [57] \\
\hline \multirow[t]{6}{*}{$\begin{array}{l}\text { Cerebral edema or intracranial } \\
\text { hypertension }\end{array}$} & ICP $>30 \mathrm{mmHg}$ or $\mathrm{CPP}<60 \mathrm{mmHg}$ & \multirow[t]{6}{*}{$\begin{array}{l}\text { Cranial trauma and/or clinical suspicion } \\
\text { of high ICP }\end{array}$} & \multirow[t]{6}{*}{ Intracranial hypertension } \\
\hline & $\begin{array}{l}\text { Massive hemoptysis requiring an } \\
\text { immediate surgical or interventional } \\
\text { radiology procedure }\end{array}$ & & \\
\hline & $\begin{array}{l}\text { Tracheal surgery or sternotomy during } \\
\text { the previous } 15 \text { days except for airway } \\
\text { access }\end{array}$ & & \\
\hline & $\begin{array}{l}\text { Serious facial trauma or facial surgery } \\
\text { during the previous } 15 \text { days }\end{array}$ & & \\
\hline & $\begin{array}{l}\text { Deep venous thrombosis treated for } \\
\text { less than } 2 \text { days }\end{array}$ & & \\
\hline & $\begin{array}{l}\text { Cardiac pacemaker inserted in the last } \\
2 \text { days }\end{array}$ & & \\
\hline Fractures of the spine & $\begin{array}{l}\text { Unstable spine, femur, or pelvic frac- } \\
\text { tures }\end{array}$ & Pelvic and/or spine fractures & Spine or pelvic fracture \\
\hline \multirow[t]{3}{*}{ Severe hemodynamic instability } & MAP $<65 \mathrm{mmHg}$ & & \\
\hline & Pregnancy & & \\
\hline & Single anterior chest tube with air leaks & & \\
\hline
\end{tabular}

$I C P$ intracranial pressure, $C P P$ cerebral perfusion pressure, $M A P$ mean arterial pressure

laser desorption/ionization [MALDI]) shortening total run time to less than $8 \mathrm{~h}$ are available $[61,62]$.

Tracheobronchial secretion should be investigated using quantitative BAL (100-120 $\mathrm{ml} 0.9 \% \mathrm{NaCl})$ or mini-non-bronchoscopic BAL (20-40 ml $0.9 \% \mathrm{NaCl})$, especially in (hypoxemic) situations were bronchoscopyguided BAL might be too invasive [63]. The cutoff for significant number of colony forming units to differentiate between colonization and infection depends on the diagnostic test: tracheobronchial secretion, 10-5 CFU/ $\mathrm{ml}$; BAL, 10-4 CFU/ml; and protected specimen brush, 10-3 CFU/ml [64]. Gram-staining is still recommended, since in patients without anti-infective treatment a high negative predictive value is documented. For exclusion of atypical pneumonia, Legionella antigen assessment (urine, sputum) with two negative tests is recommended. New molecular assays as part of a panel for viral pneumonia (influenza A with two subtypes, parainfluenza 1-4) and atypical pathogens with a short run time are available. In ICU patients with influenza-associated pneumonia at risk for bacterial co-infections, a 5-day delay for treatment of seasonal influenza and influenza-associated infection is reported (Table 3) [65]. Of note careful examination may help to exclude some clinical entities that are mistaken for ARDS (e.g., idiopathic pulmonary fibrosis, cryptogenic organizing pneumonia, nonspecific interstitial pneumonitis, Wegener's granulomatosis, or acute eosinophilic pneumonia). These diseases need of course a lung-protective strategy (limitation of $V_{\mathrm{T}}$ ), but some other ARDS-specific measures as addressed in this article are not proven and may not be "automatically" helpful $[66,67]$. Various diagnostic tools of BAL analysis (hemogram, cytology, and flow cytometric analysis) have been described as a complete diagnostic workup [68]. In immunosuppressed patients specific diagnostic and therapeutic procedures are essential. Pretreatment with antiinfectives, local resistance, and severity of illness with organ failure have to be considered for calculated use of broad-spectrum antibiotics [69]. Targeted treatment after successful detection of the responsible pathogen is more effective and lowers mortality. Moreover, de-escalation and targeted anti-infective treatment of pneumonia reduce superinfection with resistant pathogens.

To diagnose sepsis resulting from invasive candidiasis, early BCs and laboratory examinations (e.g., $\beta$-D-Glucan) are recommended. Open lung biopsy should not be performed to demonstrate the presence of diffuse alveolar damage, but only considered if there is high clinical suspicion of contributive results for (risky) empirical therapy or when empirical therapy has failed [70]. Immunosuppressed patients are at high risk of invasive pulmonary aspergillosis. In these patients BAL galactomannan levels in CT-suspected areas are more sensitive and specific than in serum [71]. New diagnostic methods using lateral flow devices might enable bedside diagnoses in the future [72].

In conclusion, ARDS patients with suspected infection are candidates for advanced broad-spectrum antibiotics after obtaining BCs and fiber bronchoscopy results, and a daily reassessment of de-escalation is recommended as 
Table 3 Diagnostic procedures for infection management in patients with severe ARDS (c/o Standard Operating Procedure, Charitè Berlin). All these diagnostic measures are subject to individual patient assessments and indications

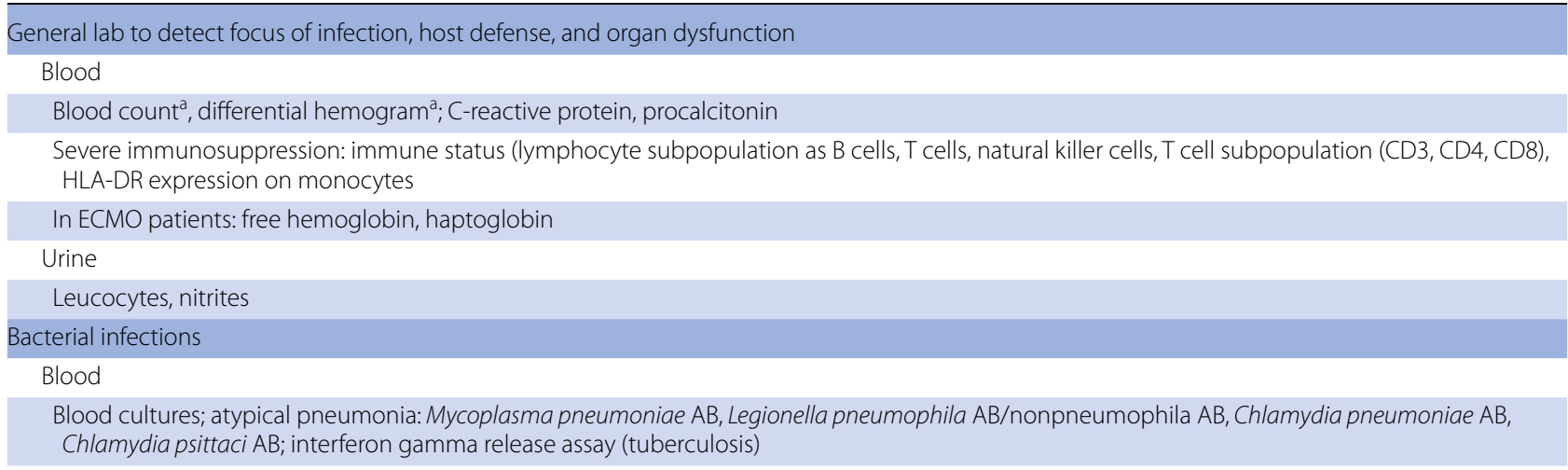
TBS/BAL

Culturing bacteria on pathogen level and resistance; direct preparation and number of granulocytes/number of epithelium cells; direct immune fluorescence (DIF) for legionella; PCR for tuberculosis and acid-resistant rod, Giemsa staining for Pneumocystis jirovecii Urine

Culturing bacteria on pathogen level and resistance; Legionella pneumophila antigen/nonpneumophila antigen; Streptococcus pneumoniae antigen Viral infections ${ }^{\mathrm{b}}$

Blood

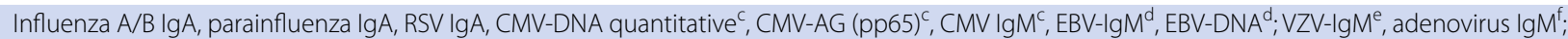
HSV1/2-lgM ${ }^{9}$

TBS/BAL

Influenza A/B virus RNA, influenza virus Ag, parainfluenza virus RNA, influenza H1N1 (2009) RNA RSV-Ag; CMV-DNAcq/q; EBV-DNAq/q ; VZV-DNA ; adenovirus-DNA ; HSV Typ1/2-DNA

Laryngo-pharyngeal scrape test

H1N1-RNA

Mycoses

Blood

Aspergillus -AG (galactomannan), candida AG/AB (manna-anti-mannan); biopsies for invasive mycosis, e.g., intra-abdominal mycoses; $\beta$-D-glucan ${ }^{h}$ TBS/BAL

Aspergillus AG (galactomannan)

Autoimmune disease to detect vasculitis, M. Wegener/sarcoidosis, Goodpasture syndrome, Hamman-Rich syndrome

Blood

Rheumatoid factor; IgA/M, antinuclear antibody (ANA/HEp2), anti-dsDNS-Ak/ELISA, glomerular basal membrane Ab, anti-mitochondrial-Ab (AMA), CANCA-ELISA (PR3), PANCA-ELISA (MPO)

TBS/BAL

Differential hemogram; cytology

Urine

Protein

TBS tracheobronchial secretion obtained by noninvasive technique in intubated patients using suction catheter, $B A L$ bronchioalveolar lavage obtained invasively by bronchoscopy

a Differential blood count is useful to differentiate between bacterial infection, viral infection, mycosis, and immunological diseases

b Multiplex respiratory panel is available (e.g., PCR for influenza A/B virus, including/H1-2009 and influenza A/H3, parainfluenza 1-4, RSV, adenovirus, coronavirus,

Bordetella pertussis, Chlamydia pneumoniae,Mycoplasma pneumoniae)

c Cytomegalovirus (CMV) reactivation in ARDS patients is typical in later clinical course and is associated with ICU mortality

d Significant number of ICU patients present Ebstein-Barr-Virus (EBV) detection in lower respiratory tract and in serum, which is associated with higher mortality than in EBV-negative patients

e Severe varicella-zoster pneumonia resulting in ARDS and multiple organ dysfunction has been reported

f Adenovirus pneumonia in ARDS has been described and was associated with high ICU mortality

$g$ Herpes-Simplex-Virus (HSV) viremia is common in ICU patients, high number of copies might be a risk factor for mechanical ventilation and ICU mortality

h $\beta$-D-Glucan for diagnosis of mycoses is recommended, but not available in routine labs 
well as a strict infection prevention strategy including all aspects of interfering determinants of VAP [73].

\section{Supportive therapies}

\section{Neuromuscular blockade}

In ARDS patients with a $\mathrm{PaO}_{2} / \mathrm{FiO}_{2}$ ratio lower than $150 \mathrm{mmHg}$ early treatment with continuous infusion of cisatracurium for $48 \mathrm{~h}$ reduces 90 -day mortality and barotrauma and increases the number of ventilator-free days and the number of days outside the ICU without increasing the risk of ICU-acquired weakness [74]. The precise mechanism resulting in improved outcomes is not clear. In terms of lung mechanics, better synchrony may lead to more-uniform lung recruitment and improved compliance, gas exchange, and systemic oxygenation. With respect to lung inflammation, it is plausible that improved control of inspiratory volumes and pressures reduces volutrauma, while better control of expiratory volumes and pressures reduces atelectrauma; the result is less pulmonary and systemic inflammation [75]. According to the study protocol, clinicians did not monitor the depth of paralysis with peripheral nerve stimulation, but rather when plateau pressures exceeded $32 \mathrm{cmH}_{2} \mathrm{O}$ (for more than $10 \mathrm{~min}$, despite increased sedation) an intravenous bolus of cisatracurium was administered. The outcome benefit for rescue therapy with neuromuscular blockade is applicable only to cisatracurium besylate and not to all neuromuscular blocking agents. Optimal dosing and monitoring strategies will need to be further studied.

\section{Sedation}

Sedation management during the early phase of ARDS is managed according to the need for neuromuscular blocking agents and to promote lung-protective ventilation. There are no randomized trials suggesting clinical advantages of any particular sedative. However, propensity score analysis of a large multicenter ICU database suggested that benzodiazepine infusions were independently associated with higher mortality and longer durations of ICU stay and ventilator support compared with propofol [76].

If the ARDS patient does not meet criteria for continuous muscle paralysis or as soon as neuromuscular blocking agents are no longer required, clinicians should target light sedation, with frequent assessment of pain and sedation, using validated scales. Sedation should be managed according to the approach proposed in the 2013 guidelines for management of pain, agitation, and delirium [77]. A randomized trial by Mehta and colleagues found that daily sedation interruption (DSI) provided no additional benefit when a nurse-directed sedation protocol is used [78]; a systematic review of nine trials and 1282 patients also concluded there is no strong evidence that DSI alters the duration of mechanical ventilation, mortality, or length of ICU or hospital stay [79]. Although the evidence for light or no sedation in mechanically ventilated critically ill patients is likely to be enhanced in the future, there are no data regarding sedation management in patients with severe hypoxemia, but in these critical situations a deep sedation within $48 \mathrm{~h}$ after onset might be advantageous.

\section{Pulmonary vasodilators}

Despite significant improvements in oxygenation, inhaled nitric oxide (iNO) does not reduce mortality in patients with ARDS regardless of the severity of hypoxemia, and it may increase the risk of renal impairment [80]. A recent meta-analysis which included nine randomized trials ( $n=1142$ patients) with no between-trial heterogeneity $(I=0 \%)$ showed that iNO did not reduce mortality in patients with severe ARDS (risk ratio 1.01; $95 \%$ CI $0.78-$ 1.32) nor in mild-moderate ARDS (risk ratio 1.12; $95 \%$ CI 0.89-1.42) [81]. Moreover, analysis of $\mathrm{PaO}_{2} / \mathrm{FiO}_{2}$ ratio subgroups ranging from 70 to $200 \mathrm{mmHg}$ did not identify a threshold for which iNO reduces mortality [80]. The effectiveness, safety, and cost of inhaled epoprostenol (iEPO) versus iNO was addressed by a retrospective single-center study of 105 patients [82], but there were no between-group differences in several clinical and outcome parameters.

\section{Control of fluid balance/hemofiltration}

Conservative fluid management during ARDS with the use of furosemide was associated with improved lung function and reduced duration of mechanical ventilation without increasing nonpulmonary organ failures [83], although there was no significant difference in the primary outcome of 60-day mortality. Furthermore, a single-center study suggested that early treatment with hemofiltration as a rescue treatment for patients with ARDS may reduce cytokine levels and systemic inflammatory response, improve cardiac function, and decrease extravascular lung water index, all of which were associated with improved outcomes [84]; however, larger trials are needed. A 65-patient single-center trial published in Chinese found that patients randomized to continuous high-volume hemofiltration had better oxygenation, reduced duration of mechanical ventilation, and improved survival compared with standard care [85].

\section{Other supportive therapies}

The incidence of gastrointestinal stress bleeding in intensive care patients is low, the prognostic importance is ambiguous, but gastrointestinal stress bleeding prophylaxis is widely used in ICUs worldwide. In a systematic 
review it was demonstrated that sufficient evidence for the use of such a prophylaxis is low [86]. Early and low dose Glucocorticoids (GC) (methylprednisolone $1 \mathrm{mg} /$ $\mathrm{kg} /$ day, then dose tapering) might accelerate the resolution of ARDS and could contribute to reduction of mortality without the risk of increasing infection [87], but it is still controversially discussed. Deep vein thromboembolism (DVE) prophylaxis is a routine measure in immobilized ICU patients, and in ARDS patients recommendations are similar to other patient groups [60]: daily unfractionated or low molecular weight heparin should be given for DVE prophylaxis according to the institution's algorithm including contraindications and modes of applications (subcutaneously or continuously via the venous route). In ECMO patients a specific strategy in terms of anticoagulation is mandatory [88]. Backrest elevated position $\left(20-45^{\circ}\right)$ is the preferred supine position for ARDS patients, since it may contribute to an improvement of oxygenation and respiratory mechanics [89] compared to "flat" supine, but limitations for backrest elevation (e.g., hemodynamic impairment) must be considered.

\section{Conclusions}

Severe ARDS is often associated with refractory hypoxemia, and early identification and treatment are mandatory [90]; however, a "simple" definition of life-threating hypoxemia has not been identified. Specific ventilator settings comprising limitation of tidal volume, adequate high PEEP, a recruitment maneuver (open lung approach) in special situations, I:E ratio $=1: 1$ with a "balanced" respiratory rate as well as prone position (early and prolonged) are recommended in a specific "timetable" (Fig. 1). Additionally, neuromuscular blockade (within $48 \mathrm{~h}$ after onset of ARDS) and an adequate sedation strategy are important supportive therapies (Fig. 2). The inhalation of pulmonary vasodilators and/or the use of hemofiltration aimed at negative fluid balance might be indicated for specific indications. An advanced infection management/control includes early diagnosis

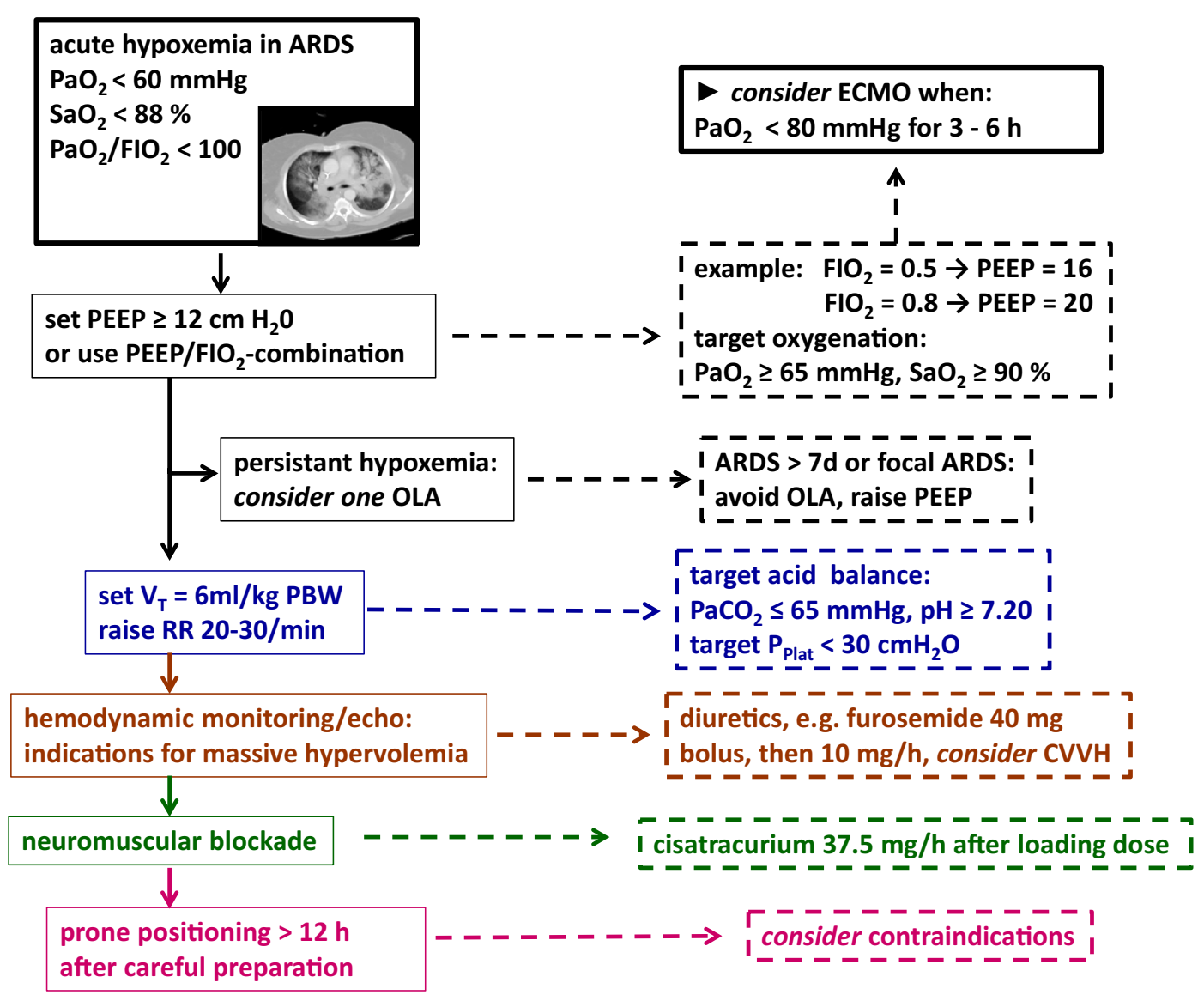

Fig. 1 A "timetable" for the acute management of hypoxemia in ARDS patients. The sequence of important measures in the hypoxemic (early) phase is given. PEEP positive end-expiratory pressure, $P_{\text {Plat }}$ plateau pressure, OLA open lung approach, $P B W$ predicted body weight, $C W H$ continuous venovenous hemofiltration 


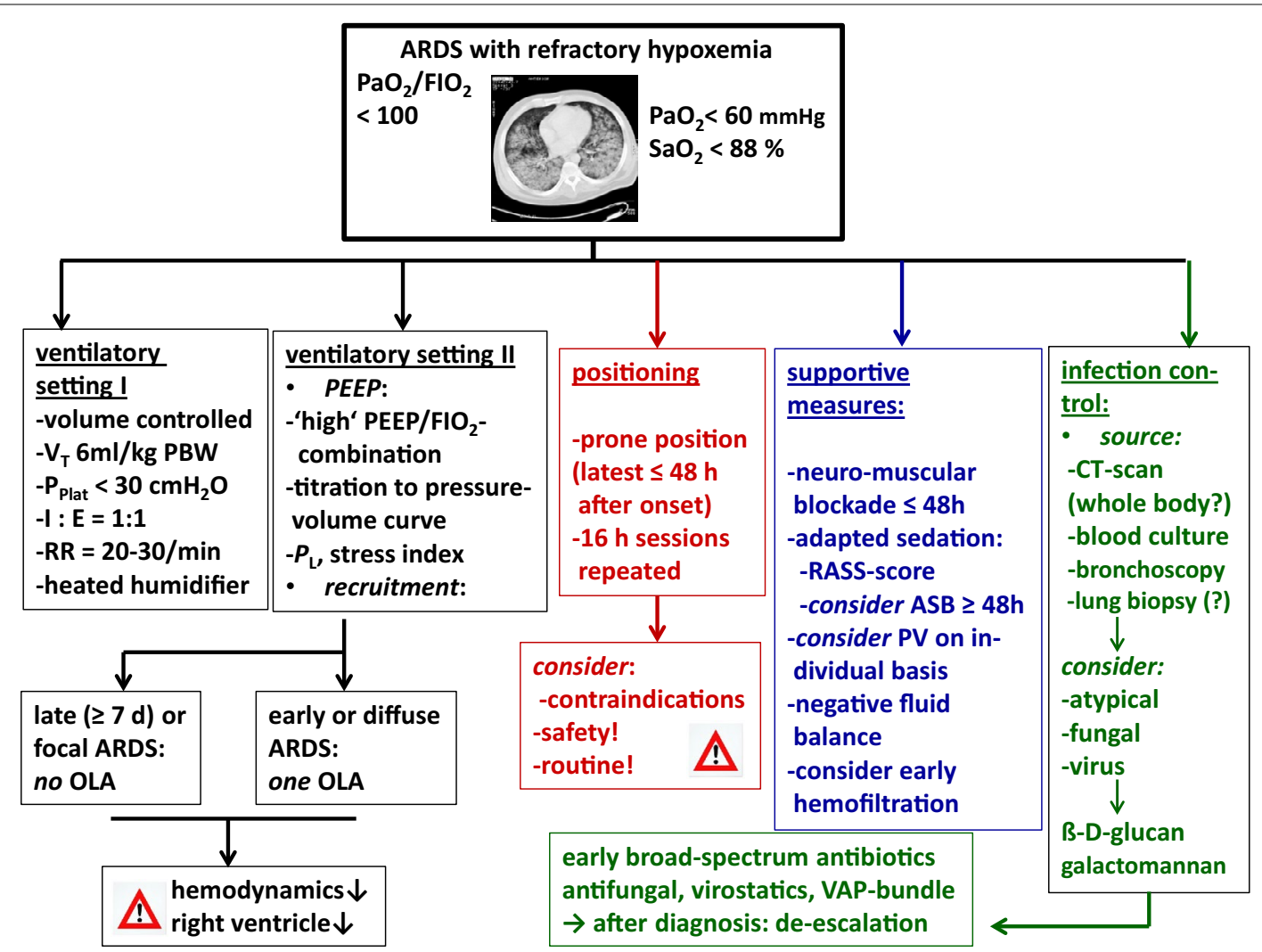

Fig. 2 Algorithm for rescue therapies in ARDS patients with refractory hypoxemia. An overview of important therapeutic strategies in the management of hypoxemic (early) ARDS. PEEP positive end-expiratory pressure, $P_{\mathrm{L}}$ transpulmonary pressure, $P_{\text {Plat }}$ plateau pressure, OLA open lung approach, $P B W$ predicted body weight, l:E inspiratory/expiratory ratio, RASS Richmond agitation sedation scale, ASB augmented spontaneous breathing, PV pulmonary vasodilator, VAP ventilator-associated pneumonia

of bacterial, atypical, viral, and fungal specimen (BC, BAL) and of infection sources by CT scan, followed by broad-spectrum anti-infectives. Various techniques of extracorporeal lung support are discussed in recent years as rescue measures in severe hypoxemic ARDS, but these specific measures are not in the scope of this article, and they are described extensively elsewhere. Actual mortality rates in ARDS patients are presented in Table 4. A large recent database of 2377 ARDS patients from 50 countries [91] indicates a different mortality in terms of the grade of the severity with the highest mortality rate of $46.1 \%$ for those patients with severe ARDS.

Table 4 Outcomes after ARDS: current data and subset analyses

\begin{tabular}{|c|c|c|}
\hline Study, region, and time of data recording & Database & Mortality \\
\hline Brun-Bruisson, ALIVE study, 10 European countries, 1999 & 401 ARDS patients & Hospital mortality $57.9 \%$ \\
\hline Villar, ALIEN study, Spain, 2008/2009 & 255 ARDS patients & Hospital mortality $47.8 \%$ \\
\hline $\begin{array}{l}\text { Bellani, LUNG-SAFE study, } 50 \text { countries across five continents, } \\
2014\end{array}$ & 2377 ARDS patients & $\begin{array}{l}\text { Hospital mortality } \\
\text { Mild ARDS } 34.9 \% \\
\text { Moderate ARDS } 40.3 \% \\
\text { Severe ARDS } 46.1 \%\end{array}$ \\
\hline Howard, USA, 2005-2013 & 183 trauma patients with ARDS & Hospital mortality $35 \%$ \\
\hline Barbier, France 2009 & $\begin{array}{l}43 \text { immunocompromised patients (HIV) with acute respiratory } \\
\text { failure }\end{array}$ & Hospital mortality $19.7 \%$ \\
\hline Davies, Australia, New Zealand, 2009 & $\begin{array}{l}68 \text { patients with influenza A (H1N1)-associated ARDS treated } \\
\text { with ECMO }\end{array}$ & Hospital mortality $21 \%$ \\
\hline Blum, USA, 2004 & 93 patients developing ARDS postoperatively & 28-day mortality $22 \%$ \\
\hline
\end{tabular}




\section{Author details}

1 Department of Anesthesia, Operative Intensive Care, University Hospital Regensburg, 93042 Regensburg, Germany. ${ }^{2}$ Dipartimento dell'Emergenza e Trapianti d'Organo (DETO), Sezione di Anestesiologia e Rianimazione, Università degli Studi di Bari “Aldo Moro", Bari, Italy. ${ }^{3}$ Department of Anaesthesiology, Emergency and Intensive Care Medicine, University Medicine, Georg-AugustUniversity, Goettingen, Germany. ${ }^{4}$ Reanimation Medicale, Hopital de la Croix Rousse, Hospices Civils de Lyon, Université de Lyon, Lyon, France. ${ }^{5}$ INSERM 955 Equipe 13, Créteil, France. ${ }^{6}$ Department of Anesthesia and Operative Intensive Care, Charitè Universitätsmedizin Berlin, Campus Virchow Klinikum and Campus Charitè Mitte, Berlin, Germany. ${ }^{7}$ Department of Medicine and Interdepartmental Division of Critical Care Medicine, Mount Sinai Hospital and University of Toronto, Toronto, Canada.

\section{Compliance with ethical standards}

\section{Conflicts of interest}

All authors declare no conflicts of interest.

Open Access This article is distributed under the terms of the Creative Commons Attribution-NonCommercial 4.0 International License (http:// creativecommons.org/licenses/by-nc/4.0/), which permits any noncommercial use, distribution, and reproduction in any medium, provided you give appropriate credit to the original author(s) and the source, provide a link to the Creative Commons license, and indicate if changes were made.

\section{Received: 18 February 2016 Accepted: 10 March 2016}

\section{Published online: 4 April 2016}

\section{References}

1. Richard C (1996) Tissue hypoxia. How to detect, how to correct, how to prevent? Intensive Care Med 22:1250-1257

2. Maclntyre NR (2013) Supporting oxygenation in acute respiratory failure. Respir Care 58:142-150

3. Abdelsalam M, Cheifetz IM (2010) Goal-directed therapy for severely hypoxic patients with acute respiratory distress syndrome: permissive hypoxemia. Respir Care 55:1483-1490

4. Vincent JL, De Backer D (2004) Oxygen transport-the oxygen delivery controversy. Intensive Care Med 30:1990-1996

5. Gilbert-Kawai ET, Mitchell K, Martin D, Carlisle J, Grocott MP (2014) Permissive hypoxaemia versus normoxaemia for mechanically ventilated critically ill patients. Cochrane Database Syst Rev 5:CD009931

6. Mikkelsen ME, Christie JD, Lanken PN, Biester RC, Thompson BT, Bellamy SL, Localio AR, Demissie E, Hopkins RO, Angus DC (2012) The adult respiratory distress syndrome cognitive outcomes study: long-term neuropsychological function in survivors of acute lung injury. Am J Respir Crit Care Med 185:1307-1315

7. Martin DS, Grocott MP (2013) Oxygen therapy in critical illness: precise control of arterial oxygenation and permissive hypoxemia. Crit Care Med 41:423-432

8. Network TA (2000) Ventilation with lower tidal volumes as compared with traditional tidal volumes for acute lung injury and the acute respiratory distress syndrome. The Acute Respiratory Distress Syndrome Network. N Engl J Med 342:1301-1308

9. Terragni PP, Rosboch G, Tealdi A, Corno E, Menaldo E, Davini O et al (2007) Tidal hyperinflation during low tidal volume ventilation in acute respiratory distress syndrome. Am J Respir Crit Care Med 175:160-166

10. Gattinoni L, Marini JJ, Pesenti A, Quintel M, Mancebo J, Brochard L (2016) The "baby lung" became an adult. Intensive Care Med. doi:10.1007/ s00134-015-4200-8

11. Terragni PP, Filippini C, Slutsky AS, Birocco A, Tenaglia T, Grasso S, Stripoli T, Pasero D, Urbino R, Fanelli V, Faggiano C, Mascia L, Ranieri VM (2013) Accuracy of plateau pressure and stress index to identify injurious ventilation in patients with acute respiratory distress syndrome. Anesthesiology 119:880-889

12. Amato MB, Meade MO, Slutsky AS, Brochard L, Costa EL, Schoenfeld DA, Stewart TE, Briel M, Talmor D, Mercat A, Richard JC, Carvalho CR, Brower
RG (2015) Driving pressure and survival in the acute respiratory distress syndrome. New Engl J Med 372:747-755

13. Ferrando C, Suárez-Sipmann F, Gutierrez A, Tusman G, Carbonell J, García M, Piqueras L, Compañ D, Flores S, Soro M, Llombart A, Belda FJ (2015) Adjusting tidal volume to stress index in an open lung condition optimizes ventilation and prevents overdistension in an experimental model of lung injury and reduced chest wall compliance. Crit Care 19:R9

14. Chacko B, Peter JV, Tharyan P, John G, Jeyaseelan L (2015) Pressure-controlled versus volume-controlled ventilation for acute respiratory failure due to acute lung injury (ALI) or acute respiratory distress syndrome (ARDS). Cochrane Database Syst Rev 14:CD008807

15. Rittayamai N, Katsios CM, Beloncle F, Friedrich JO, Mancebo J, Brochard $L$ (2015) Pressure-controlled vs volume-controlled ventilation in acute respiratory failure: a physiology-based narrative and systematic review. Chest 148:340-355

16. Facchin F, Fan E (2015) Airway pressure release ventilation and highfrequency oscillatory ventilation: potential strategies to treat severe hypoxemia and prevent ventilator-induced lung injury. Respir Care 60:1509-1521

17. Protti A, Andreis DT, Monti M, Santini A, Sparacino CC, Langer T, Votta E, Gatti S, Lombardi L, Leopardi O, Masson S, Cressoni M, Gattinoni L (2013) Lung stress and strain during mechanical ventilation: any difference between statics and dynamics? Crit Care Med 41:1046-1055

18. Tschumperlin DJ, Oswari J, Margulies AS (2000) Deformation-induced injury of alveolar epithelial cells: effect of frequency, duration, and amplitude. Am J Respir Crit Care Med 162:357-362

19. Conrad SA, Zhang S, Arnold TC, Scott LK, Carden DL (2005) Protective effects of low respiratory frequency in experimental ventilator-associated lung injury. Crit Care Med 33:835-840

20. Baumgardner JE, Markstaller K, Pfeiffer B, Doebrich M, Otto CM (2002) Effects of respiratory rate, plateau pressure, and positive end-expiratory pressure on $\mathrm{PaO}_{2}$ oscillations after saline lavage. Am J Respir Crit Care Med 166:1556-1562

21. Neumann P, Berglund JE, Mondejar EF, Magnusson A, Hedenstierna G (1998) Effect of different pressure levels on the dynamics of lung collapse and recruitment in oleic-acid-induced lung injury. Am J Respir Crit Care Med 158:1636-1643

22. Mercat A, Titiriga M, Anguel N, Richard C, Teboul JL (2001) Inverse ratio ventilation $(/ / E=2 / 1)$ in acute respiratory distress syndrome: a six-hour controlled study. Am J Respir Crit Care Med 155:1637-1642

23. Boehme S, Bentley AH, Hartmann EK, Chang S, Erdoes G, Prinzing A, Hagmann M, Baumgardner JE, Ullrich R, Markstaller K, David M (2015) Influence of inspiration to expiration ratio on cyclic recruitment and derecruitment of atelectasis in a saline lavage model of acute respiratory distress syndrome. Crit Care Med 43:e65-e74

24. Lee SM, Kim WH, Ahn HJ, Kim JA, Yang MK, Lee CH, Lee JH, Kim YR, Choi JW (2013) The effects of prolonged inspiratory time during one-lung ventilation: a randomized controlled trial. Anaesthesia 68:908-916

25. Casetti AV, Bartlett RH, Hirschl RB (2002) Increasing inspiratory time exacerbates ventilator-induced lung injury during high-pressure/high-volume mechanical ventilation. Crit Care Med 30:2295-2299

26. American Association for Respiratory Care, Restrepo RD, Walsh BK (2012) Humidification during invasive and noninvasive mechanical ventilation. Respir Care 57:782-788

27. Prat G, Renault A, Tonnelier JM, Goetghebeur D, Oger E, Boles JM, L'Her E (2003) Influence of the humidification device during acute respiratory distress syndrome. Intensive Care Med 29:2211-2215

28. Prin S, Chergui K, Augarde R, Page B, Jardin F, Vieillard-Baron A (2002) Ability and safety of a heated humidifier to control hypercapnic acidosis in severe ARDS. Intensive Care Med 28:1756-1760

29. Morán I, Bellapart J, Vari A, Mancebo J (2006) Heat and moisture exchangers and heated humidifiers in acute lung injury/acute respiratory distress syndrome patients. Effects on respiratory mechanics and gas exchange. Intensive Care Med 32:524-531

30. Petty TL, Ashbaugh DG (1971) The adult respiratory distress syndrome. Clinical features, factors influencing prognosis and principles of management. Chest 60:233-239

31. Tremblay LN, Slutsky AS (2006) Ventilator-induced lung injury: from the bench to the bedside. Intensive Care Med 32:24-33 
32. Meade MO, Cook DJ, Guyatt GH, Slutsky AS, Arabi YM, Cooper DJ, Davies AR, LE Hand, Zhou Q, Thabane L, Austin P, Lapinsky S, Baxter A, Russell J, Skrobik Y, Ronco JJ, Stewart TE, Lung Open Ventilation Study Investigators (2008) Ventilation strategy using low tidal volumes, recruitment maneuvers, and high positive end-expiratory pressure for acute lung injury and acute respiratory distress syndrome: a randomized controlled trial. JAMA 299:637-645

33. Mercat A, Richard JC, Vielle B, Jaber S, Osman D, Diehl JL et al (2008) Positive end-expiratory pressure setting in adults with acute lung injury and acute respiratory distress syndrome: a randomized controlled trial. JAMA 299:646-655

34. Brower RG, Lanken PN, MacIntyre N, Matthay MA, Morris A, Ancukiewicz M, Schoenfeld D, Thompson BT, National Heart Lung, and Blood Institute ARDS Clinical Trials Network (2004) Higher versus lower positive end-expiratory pressures in patients with the acute respiratory distress syndrome. N Engl J Med 351:327-336

35. Suzumura EA, Figueiró M, Normilio-Silva K, Laranjeira L, Oliveira C, Buehler AM, Bugano D, Passos Amato MB, Ribeiro Carvalho CR, Berwanger O, Cavalcanti AB (2014) Effects of alveolar recruitment maneuvers on clinical outcomes in patients with acute respiratory distress syndrome: a systematic review and meta-analysis. Intensive Care Med 40:1227-1240

36. Cinnella G, Grasso S, Raimondo P, D’Antini D, Mirabella L, Dambrosio RM (2015) Physiological effects of the open lung approach in patients with early, mild, diffuse acute respiratory distress syndrome: an electrical impedance tomography study. Anesthesiology 123:1113-1121

37. Briel M, Meade M, Mercat A, Brower RG, Talmor D, Walter SD et al (2010) Higher vs lower positive end-expiratory pressure in patients with acute lung injury and acute respiratory distress syndrome: systematic review and meta-analysis. JAMA 303:865-873

38. Kacmarek RM, Villar J (2013) Management of refractory hypoxemia in ARDS. Minerva Anestesiol 79:1173-1179

39. Papazian L, Forel JM, Gacouin A, Penot-Ragon C, Perrin G, Loundou A, Jaber S, Arnal JM, Perez D, Seghboyan JM, Constantin JM, Courant P, Lefrant JY, Guérin C, Prat G, Morange S, Roch A, ACURASYS Study Investigators (2010) Neuromuscular blockers in early acute respiratory distress syndrome. N Engl J Med 363:1107-1116

40. Grasso S, Terragni P, Birocco A, Urbino R, Del Sorbo L, Mascia FCL, Pesenti A, Zangrillo A, Gattinoni L, Ranieri VM (2012) ECMO criteria for influenza A (H1 N1)-associated ARDS: role of transpulmonary pressure. Intensive Care Med 38:395-403

41. de Matos GF, Stanzani F, Passos RH, Fontana MF, Albaladejo R, Caserta RE, Santos DC, Borges JB, Amato MB, Barbas CS (2012) How large is the lung recruitability in early acute respiratory distress syndrome: a prospective case series of patients monitored by computed tomography. Crit Care 16:R4

42. Gattinoni L, Caironi P, Cressoni M, Chiumello D, Ranieri VM, Russo QMS, Patroniti N, Cornejo R, Bugedo G (2006) Lung recruitment in patients with the acute respiratory distress syndrome. N Engl J Med 354:1775-1786

43. Constantin JM, Grasso S, Chanques G, Aufort S, Futier E, Sebbane M, Jung B, Gallix B, Bazin JE, Rouby JJ, Jaber S (2010) Lung morphology predicts response to recruitment maneuver in patients with acute respiratory distress syndrome. Crit Care Med 38:1108-1117

44. Rehberg S, Ertmer C, Westphal M (2009) Mechanical ventilation in patients with ARDS: is the lung's fortune the right ventricle's poison? Intensive Care Med 35:1825-1826

45. Mure M, Martling CR, Lindahl SG (1997) Dramatic effect on oxygenation in patients with severe acute lung insufficiency treated in the prone position. Crit Care Med 25:1539-1544

46. Sud S, Friedrich JO, Taccone P, Polli F, Adhikari NK, Latini R, Pesenti A, Guerin C, Mancebo J, Curley MA, Fernandez R, Chan MC, Beuret P, Voggenreiter G, Sud M, Tognoni G, Gattinoni L (2010) Prone ventilation reduces mortality in patients with acute respiratory failure and severe hypoxemia: systematic review and meta-analysis. Intensive Care Med 36:585-599

47. Gattinoni L, Carlesso E, Taccone P, Polli F, Guerin C, Mancebo J (2010) Prone positioning improves survival in severe ARDS: a pathophysiologic review and individual patient meta-analysis. Minerva Anestesiol 76:448-454

48. Guérin C, Reignier J, Richard JC, Beuret P, Gacouin A, Boulain T, Mercier E, Badet M, Mercat A, Baudin O, Clavel M, Chatellier D, Jaber S, Rosselli S, Mancebo J, Sirodot M, Hilbert G, Bengler C, Richecoeur J, Gainnier M, Bayle F, Bourdin G, Leray V, Girard R, Baboi L, Ayzac L, PROSEVA Study
Group (2013) Prone positioning in severe acute respiratory distress syndrome. N Engl J Med 368:2159-2168

49. Albert RK, Keniston A, Baboi L, Ayzac L, Guerin C, Proseva I (2014) Prone position-induced improvement in gas exchange does not predict improved survival in the acute respiratory distress syndrome. Am J Respir Crit Care Med 189:494-496

50. Cornejo RA, Diaz JC, Tobar EA, Bruhn AR, Ramos CA, Gonzalez RA, Repetto CA, Romero CM, Galvez LR, Llanos O, Arellano DH, Neira WR, Diaz GA, Zamorano AJ, Pereira GL (2013) Effects of prone positioning on lung protection in patients with acute respiratory distress syndrome. Am J Respir Crit Care Med 188:440-448

51. Guerin C, Baboi L, Richard JC (2014) Mechanisms of the effects of prone positioning in acute respiratory distress syndrome. Intensive Care Med 40:1634-1642

52. Mentzelopoulos SD, Roussos C, Zakynthinos SG (2005) Prone position reduces lung stress and strain in severe acute respiratory distress syndrome. Eur Respir J 25:534-544

53. Villar J, Pérez-Méndez L, Blanco J, Añón JM, Blanch L, Belda J, SantosBouza A, Fernández RL, Kacmarek RM, Spanish Initiative for Epidemiology, Stratification, and Therapies for ARDS (SIESTA) Network (2013) A universal definition of ARDS: the $\mathrm{PaO}_{2} / \mathrm{FiO}_{2}$ ratio under a standard ventilatory setting - a prospective, multicenter validation study. Intensive Care Med 39:583-592

54. Guérin C, Gaillard S, Lemasson S, Ayzac L, Girard R, Beuret P, Palmier B, Le QV, Sirodot M, Rosselli S, Cadiergue V, Sainty JM, Barbe P, Combourieu E, Debatty D, Rouffineau J, Ezingeard E, Millet O, Guelon D, Rodriguez L, Martin O, Renault A, Sibille JP, Kaidomar M (2004) Effects of systematic prone positioning in hypoxemic acute respiratory failure: a randomized controlled trial. JAMA 292:2379-2387

55. Gattinoni L, Tognoni G, Pesenti A, Taccone P, Mascheroni D, Labarta V, Malacrida R, Di Giulio P, Fumagalli R, Pelosi P, Brazzi L, Latini R (2001) Effect of prone positioning on the survival of patients with acute respiratory failure. N Engl J Med 345:568-573

56. Mancebo J, Fernandez R, Blanch L, Rialp G, Gordo F, Ferrer M, Rodriguez F, Garro P, Ricart P, Vallverdu I, Gich I, Castano J, Saura P, Dominguez G, Bonet A, Albert RK (2006) A multicenter trial of prolonged prone ventilation in severe acute respiratory distress syndrome. Am J Respir Crit Care Med 173:1233-1239

57. Taccone P, Pesenti A, Latini R, Polli F, Vagginelli F, Mietto C, Caspani L, Raimondi F, Bordone G, lapichino G, Mancebo J, Guerin C, Ayzac L, Blanch L, Fumagalli R, Tognoni G, Gattinoni L (2009) Prone positioning in patients with moderate and severe acute respiratory distress syndrome: a randomized controlled trial. JAMA 302:1977-1984

58. Sud S, Friedrich JO, Adhikari NK, Taccone P, Mancebo J, Polli F, Latini R, Pesenti A, Curley MA, Fernandez R, Chan MC, Beuret P, Voggenreiter G, Sud M, Tognoni G, Gattinoni L, Guerin C (2014) Effect of prone positioning during mechanical ventilation on mortality among patients with acute respiratory distress syndrome: a systematic review and meta-analysis. CMAJ 186:E381-E390

59. Bloomfield R, Noble DW, Sudlow A (2015) Prone position for acute respiratory failure in adults. Cochrane Database Syst Rev 11:CD008095

60. Dellinger RP, Levy MM, Rhodes A, Annane D, Gerlach H, Opal SM, Sevransky JE, Sprung CL, Douglas IS, Jaeschke R, Osborn TM, Nunnally ME, Townsend SR, Reinhart K, Kleinpell RM, Angus DC, Deutschman CS, Machado FR, Rubenfeld GD, Webb S, Beale RJ, Vincent IL, Moreno R, Surviving Sepsis Campaign Guidelines Committee including The Pediatric Subgroup. Surviving Sepsis Campaign (2013) International guidelines for management of severe sepsis and septic shock, 2012. Intensive Care Med 39:165-228

61. Liesenfeld O, Lehman L, Hunfeld K-P, Kost K (2014) Molecular diagnosis of sepsis: new aspects and recent developments. Eur J Microbiol Immun 4:1-25

62. Douglas IS (2016) New diagnostic methods for pneumonia in the ICU. Curr Opin Infect Dis 29:197-204

63. Flanagan PG, Findlay GP, Magee JT, Ionescu A, Barnes RA, Smithies M (2000) The diagnosis of ventilator-associated pneumonia using nonbronchoscopic, non-directed lung lavages. Intensive Care Med 26:20-30

64. Vélez Lázaro, Correa Luz Teresita, Maya Maria Angélica, Mejía Patricia, Ortega Jorge, Bedoya Victoria, Ortega Héctor (2007) Diagnostic accuracy of bronchoalveolar lavage samples in immunosuppressed patients with suspected pneumonia: analysis of a protocol. Respir Med 101:2160-2167 
65. Jain S, Benoit SR, Skarbinski J, Bramley AM, Finelli L, Pandemic Influenza A (H1N1) Virus Hospitalizations Investigation Team (2012) Influenza-associated pneumonia among hospitalized patients with 2009 pandemic influenza A (H1N1) virus-United States, 2009. Clin Infect Dis 54:1221-1229

66. Guérin C, Thompson T, Brower R (2015) The ten diseases that look like ARDS. Intensive Care Med 41:1099-1102

67. Gibelin A, Parrot A, Maitre B, Brun-Buisson C, Mekontso Dessap A, Fartoukh M, de Prost N (2016) Acute respiratory distress syndrome mimickers lacking common risk factors of the Berlin definition. Intensive Care Med 42:164-172

68. Poletti V, Ravaglia C, Gurioli C et al (2016) Invasive diagnostic techniques in idiopathic interstitial pneumonias. Respirology 21:44-50

69. Martin-Loeches I, Deja M, Koulenti D, Dimopoulos G, Marsh B, Torres A, Niederman MS, Rello J, EU-VAP Study Investigators (2013) Potentially resistant microorganisms in intubated patients with hospital-acquired pneumonia: the interaction of ecology, shock and risk factors. Intensive Care Med 39:672-681

70. Palakshappa JA, Meyer NJ (2015) Which patients with ARDS benefit from lung biopsy? Chest 148:1073-1082

71. Taccone FS, den Abeele Van et al (2015) Epidemiology of invasive aspergillosis in critically ill patients: clinical presentation, underlying condition, and outcome. Crit Care 19:7

72. Eigl S, Prattes J, Lackner M et al (2015) Multicenter evaluation of a lateralflow device test diagnosing invasive pulmonary aspergillosis in ICU patients. Crit Care 19:178

73. Deja M, Spies C (2009) Prevention measures of ventilator-associated pneumonia. Crit Care Med 37:330-332

74. Alhazzani W, Alshahrani M, Jaeschke R, Forel JM, Papazian L, Sevransky J, Meade MO (2013) Neuromuscular blocking agents in acute respiratory distress syndrome: a systematic review and meta-analysis of randomized controlled trials. Crit Care 17:R43

75. Forel JM, Roch A, Marin V, Michelet P, Demory D, Blache JL, Perrin G, Gainnier M, Bongrand P, Papazian L (2006) Neuromuscular blocking agents decrease inflammatory response in patients presenting with acute respiratory distress syndrome. Crit Care Med 34:2749-2757

76. Lonardo NW, Mone MC, Nirula R, Kimball EJ, Ludwig K, Zhou X, Sauer BC, Nechodom K, Teng C, Barton RG (2014) Propofol is associated with favorable outcomes compared with benzodiazepines in ventilated intensive care unit patients. Am J Resp Crit Care Med 189(11):1383-1394

77. Barr J, Fraser GL, Puntillo K, Ely EW, Gelinas C, Dasta JF, Davidson JE, Devlin JW, Kress JP, Joffe AM, Coursin DB, Herr DL, Tung A, Robinson BRH, Fontaine DK, Ramsay MA, Riker RR, Sessler CN, Pun B, Skrobik Y, Jaeschke R (2013) Clinical practice guidelines for the management of pain, agitation, and delirium in adult patients in the intensive care unit. Crit Care Med 41:263-306

78. Mehta S, Burry L, Cook D, Fergusson D, Steinberg M, Granton J, Herridge $\mathrm{M}$, Ferguson N, Devlin J, Tanios M, Dodek P, Fowler R, Burns K, Jacka M, Olafson K, Skrobik Y, Hebert P, Sabri E, Meade M, For the SLEAP Investigators and the Canadian Critical Care Trials Group (2012) Daily sedation interruption in mechanically ventilated critically ill patients cared for with a sedation protocol: a randomized controlled trial. JAMA 308(19):1985-1992
79. Burry L, Rose L, McCullagh IJ, Fergusson DA, Ferguson ND, Mehta S (2014) Daily sedation interruption versus no daily sedation interruption for critically ill adult patients requiring invasive mechanical ventilation. Cochrane Database Syst Rev 9:CD009176

80. Afshari A, Brok J, Moller AM, Etterslev J (2010) Inhaled nitric oxide for acute respiratory distress syndrome (ARDS) and acute lung injury in children and adults. Cochrane Database Syst Rev 7:002787

81. Adhikari NKJ, Dellinger RP, Lundin S, Payen D, Vallet B, Gerlach H, Park KJ, Mehta S, Slutsky AS, Friedrich JO (2014) Inhaled nitric oxide does not reduce mortality in patients with acute respiratory distress syndrome regardless of severity: systematic review and meta-analysis. Crit Care Med 42:404-412

82. Torbic H, Szumita PM, Anger KE, Nuccio P, LaGambina S, Weinhouse $G$ (2013) Inhaled epoprostenol vs inhaled nitric oxide for refractory hypoxemia in critically ill patients. J Crit Care 28:844-848

83. The National Heart Lung and Blood Institute Acute Respiratory Distress Syndrome (ARDS) Clinical Trials Network (2006) Comparison of two fluid-management strategies in acute lung injury. N Engl J Med 354:2564-2575

84. Kuzolev A, Tishkov E, Bukaev O (2013) Effect of continuous high-volume hemofiltration on patients with acute respiratory distress syndrome. Crit Care 17(Suppl 2):P431

85. Zhang JC, Chu YF, Zeng J, Ren HS, Meng M, Jiang JJ, Wang CT (2013) Effect of continuous high-volume hemofiltration in patients with severe acute respiratory distress syndrome. Chin Crit Care Med 25(3):145-148

86. Krag M, Perner A, Wetterslev J, Wise MP, Hylander Møller M (2014) Stress ulcer prophylaxis versus placebo or no prophylaxis in critically ill patients. A systematic review of randomised clinical trials with meta-analysis and trial sequential analysis. Intensive Care Med 40:11-22

87. Bein T, Briegel J, Annane D (2016) Steroids are part of rescue therapy in ARDS patients with refractory hypoxemia: yes. Intensive Care Med. doi:10.1007/s00134-015-4162-x

88. Richard C, Argaud L, Blet A, Boulain T, Contentin L, Dechartres A, Dejode JM, Donetti L, Fartoukh M, Fletcher D, Kuteifan K, Lasocki S, Liet JM, Lukaszewicz AC, Mal H, Maury E, Osman D, Outin H, Richard JC, Schneider F, Tamion F (2014) Extracorporeal life support for patients with acute respiratory distress syndrome: report of a consensus conference. Ann Intensive Care 24(4):15

89. Bein T, Bischoff M, Brückner U, Gebhardt K, Henzler D, Hermes C, Lewandowski K, Max M, Nothacker M, Staudinger T, Tryba M, Weber-Carstens S, Wrigge H (2015) S2e guideline: positioning and early mobilisation in prophylaxis or therapy of pulmonary disorders: revision 2015: S2e guideline of the German Society of Anaesthesiology and Intensive Care Medicine (DGAl). Anaesthesist 64(Suppl 1):1-26

90. Combes A, Ranieri M (2015) Rescue therapy for refractory ARDS should be offered early: yes. Intensive Care Med 41:923-925

91. Bellani G, Laffey JG, Pham T, Fan E, Brochard L, Esteban A, Gattinoni L, van Haren F, Larsson A, McAuley DF, Ranieri M, Rubenfeld G, Thompson BT, Wrigge H, Slutsky AS, Pesenti A, LUNG SAFE Investigators, The ESICM Trials Group (2016) Epidemiology, patterns of care, and mortality for patients with acute respiratory distress syndrome in intensive care units in 50 countries. JAMA 315:788-800 